\title{
DEEP DRILLING AT BASE ROI BAUDOUIN, DRONNING MAUD LAND, ANTARCTICA
}

\author{
By E. Tongiorgi \\ (Laboratorio di Geologia Nucleare del Comitato Nazionale per l'Energia Nucleare, \\ Universita di Pisa) \\ E. Picciotto \\ (Laboratoire de Géologie Nucléaire, Université Libre de Bruxelles) \\ W. DE BREUCK \\ (Laboratorium voor Fysische Aardrykskunde, Universiteit te Gent, and \\ Expédition Antarctique Belge, 1960) \\ T. Norling \\ (Craelius Company, Stockholm) \\ J. Giot \\ (European Atomic Energy Community, Brussels) \\ and $\mathrm{F}$. Pantanetti \\ (Divisione Geomineraria, Comitato Nazionale per l'Energia Nucleare, \\ Universita di Pisa)
}

\begin{abstract}
A drilling operation and core investigations at Base Roi Baudouin (lat. $70^{\circ} 25^{\prime} 53^{\prime \prime} \mathrm{S}$., long. $2418^{\prime} 38^{\prime \prime}$ E.) in January 1961 are discussed. The drilling, undertaken with light equipment, attained a depth of 1 I $5.72 \mathrm{~m}$. From the start serious difficulties were encountered so that it was decided to use a SIPRE auger driven by the mechanism of the drilling machine. Core recovery was close to 100 per cent. Below a depth of $43.70 \mathrm{~m}$., since the drill had reached the zone of high ice density $\left(0.85 \mathrm{~g} . / \mathrm{cm} .{ }^{3}\right)$, a $3 \mathrm{~m}$. double core barrel was used with air circulation. A depth of $79.33 \mathrm{~m}$. was reached with a core yield close to 100 per cent. From this level downwards to the final depth of $115.72 \mathrm{~m}$. the core yield was only 55 per cent.

Preliminary observations were made at the site. A stratigraphic profile of the first $43 \mathrm{~m}$. showed an alternation of coarse-grained summer layers with ice formation and fine-grained winter deposits. From the seasonal alternations of the last six years, an average annual accumulation of $3^{8} \cdot 3 \mathrm{~cm}$. of water was calculated. No coloured or dust layers were observed. Between 9 and $16 \mathrm{~m}$. and between $4 \mathrm{I}$ and $44 \mathrm{~m}$. an intense formation of ice was noticed. The depth-density curve is similar to those found by the Norwegian-British-Swedish Antarctic Expedition at Maudheim and by the Americans at Little America V. If an average annual accumulation of $38 \mathrm{~cm}$. of water is assumed, the whole depth drilled corresponds to approximately 240 yr. Temperature measurements could not be carried out because of the limited time available.

Detailed stratigraphic and morphological studies of the cores, which are stored at $-15{ }^{\circ}$. in Brussels, are planned, as well as chemical and isotopic investigations.
\end{abstract}

RÉsumé. Une opération de forage et des investigations de carottes faites à la Base Roi Baudouin $\left(7025^{\prime} 53^{\prime \prime} \mathrm{S}, 24^{\circ} 1^{\prime} 3^{8^{\prime \prime} \mathrm{E}}\right)$ en janvier 196r sont discutées. Le forage, entrepris avec un équipment léger, a atteint une profondeur de $115.72 \mathrm{~m}$. Dès le début on rencontra de sérieuses difficultés, de sorte qu'il fut decidé d'utiliser une tarière SIPRE conduite par le mécanisme de la foreuse. La récupération des carottes était voisine de 100 pour cent. En dessous de $43,70 \mathrm{~m}$ de profondeur, à partir du moment où la tarière a atteint la zone de glace de densité élevée $\left(0,85 \mathrm{~g} / \mathrm{cm}^{3}\right)$, on a utilisé un tube carottier double de $3 \mathrm{~m}$ avec circulation d'air. On a atteint une profondeur de $79.33 \mathrm{~m}$ avec un rendement de carotte voisin de 100 pour cent. A partir de ce niveau, en descendant jusqu'à la profondeur finale de ${ }_{115}, 72 \mathrm{~m}$, la récupération des carottes atteignait seulement 55 pour cent.

On a fait à cet emplacement des observations préliminaires. Un profil stratigraphique des 43 premiers mètres a montré une alternance de couches d'été à gros grains avec formation de glace et de dépôts d'hiver à grains fins. A partir des alternances saisonnières des 6 dernières années, on a calculé une accumulation moyenne annuelle de $38,3 \mathrm{~cm}$ d'eau. Aucune couche colorée ou poussiéreuse n'a été observée. Entre 9 et $16 \mathrm{~m}$ et entre 41 et $44 \mathrm{~m}$, on a noté une importante formation de glace. La courbe densité-profondeur est semblable à celles obtenues par l'Expédition Antarctique Norvégienne-Britannique-Suédoise à Maudheim et par les Américains à Little America V.Si l'on admet une accumulation moyenne annuelle de $3^{8} \mathrm{~cm}$ d'eau, la profondeur totale du trou correspond approximativement à 240 ans. Il n'a pas été possible de faire des mesures de température à cause du temps disponible limité.

Les études stratigraphiques et morphologiques détaillées des carottes, qui sont conservées à - $\mathrm{I} 5^{\circ} \mathrm{C}$ à Bruxelles, sont prévues en même temps que des investigations chimiques et isotopiques.

Zusammenfassung. Die Arbeit befasst sich mit einer Bohrung und Kernuntersuchung während des Januars I 961 in der Base Roi Baudouin ( $70^{\circ} 25^{\prime} 53^{\prime \prime}$ südl. Breite, $24^{\circ} 18^{\prime} 38^{\prime \prime}$ östl. Länge). Die Bohrung, ausgeführt 
mit leichter Ausrüstung, erreichte eine Tiefe von 115,72 m. Am Anfang stellten sich erhebliche Schwierigkeiten ein, bis auf die Benutzung eines SIPRE-Bohrers, angetrieben von der Bohrmaschine, übergegangen wurde. Der Bohrkern konnte dabei fast vollständig geborgen werden. Von 43,70 m Tiefe an, wo die Bohrung die Zone hoher Eisdichte $\left(0,85 \mathrm{~g} / \mathrm{cm}^{3}\right)$ erreicht hatte, wurde ein $3 \mathrm{~m}$ langes Doppel-Kernbohrrohr mit Luftspülung verwendet. Bis 79,33 m Tiefe blieb der Kern-Ertrag nahe an $100 \%$; von dann an bis zur Endtiefe von i i 5,72 m konnten nur $55 \%$ des Kerns geborgen werden.

Vorläufige Untersuchungen wurden an Ort und Stelle vorgenommen. Das stratigraphische Profil der ersten $43 \mathrm{~m}$ zeigte eine Wechsellagerung zwischen grobkörnigen Sommerschichten mit Blankeislagen und feinkörnigen Winterablagerungen. Der mittlere Jahresniederschlag konnte aus den jahreszeitlichen Wechsellagen der letzten 6 Jahre zu $38,3 \mathrm{~cm}$ Wasser bestimmt werden. Es fanden sich keine verfärbten oder staubdurchsetzten Schichten. Zwischen 9 und $\mathrm{I} 6 \mathrm{~m}$ sowie zwischen $4^{\mathrm{I}}$ und $44 \mathrm{~m}$ Tiefe wurde starke Eisbildung festgestellt. Das Tiefe-Dichte-Diagramm ähnelt denen, die von der Norwegisch-Britisch-Schwedischen Antarktis-Expedition in Maudheim und von den Amerikaners in Little America V gefunden wurden. Unter der Annahme eines mittleren Jahresniederschlags von $38 \mathrm{~cm}$ Wasser entspricht die erreichte Bohrtiefe einem Ablagerungszeitraum von etwa 240 Jahren. Temperaturmessungen konnten aus Zeitmangel nicht vorgenommen werden.

Stratigraphische und morphologische Detailstudien an dem Bohrkern, der bei $-{ }^{\circ}$ C in Brüssel gelagert ist, sind vorgesehen, desgleichen chemische und isotopische Untersuchungen.

\section{INTRODUCTION}

In January I96 I a boring to obtain ice specimens was undertaken at Base Roi Baudouin on the ice shelf of the Prinsesse Ragnhild Kyst (lat. $24^{\circ}$ I9' E., long. $70^{\circ} 26^{\prime}$ S.) (Figs. I and 2).

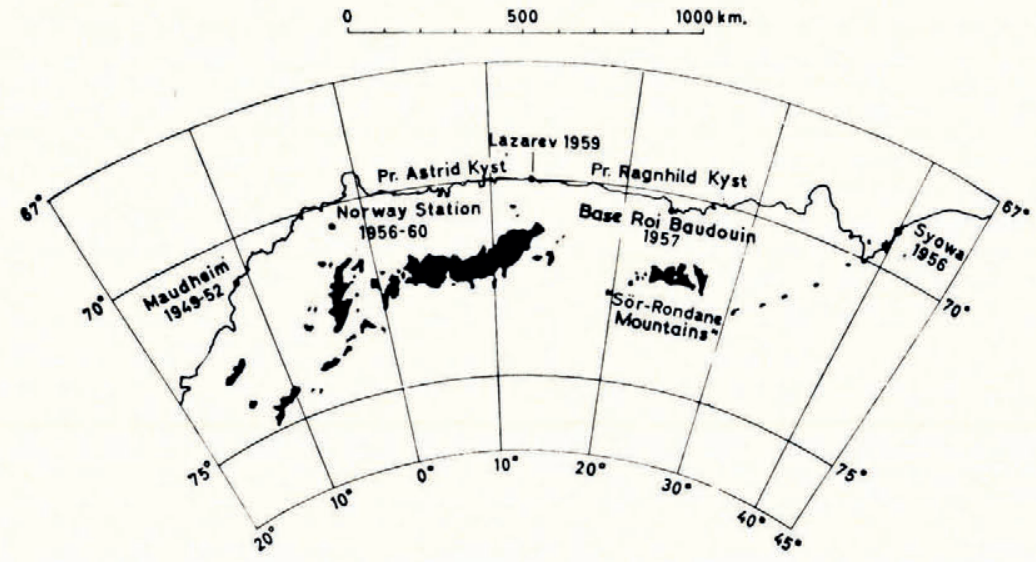

Fig. 1. Dronning Maud Land (from a diagram of the Norsk Polarinstitutt)

The principal object of the sampling was to study the isotopic composition of the ice with respect to its stratigraphic characteristics, as well as certain radio-active measurements.

The variations of the isotopic composition along a vertical section could be expected to yield information on long-term seasonal and climatic variations. Such "isotopic stratigraphy" would also assist studies on total accumulation of snow and on the ice flow. It would also enable the dating of the snow and ice layers by counting the seasonal deposits (Epstein and Sharp, I959 [a], [b]).

Measurements of radio-active isotopes such as tritium, radium $\mathrm{D}$ and fission products could, moreover, furnish useful glaciological and meteorological data (Picciotto and others, I96o; Gonfiantini and Picciotto, 1959).

The drilling project is the result of technical and financial collaboration between the Italian Comitato Nazionale per l'Energia Nucleare (C.N.E.N.), the European Atomic Energy Community (Euratom) and the Centre National de Recherches Polaires de Belgique 
(C.N.R.P.B.). Aid was given at the site of the investigations by the members of the Expédition Antarctique Belge, I960, commanded by Guy Derom.

The scientific direction of the project was carried out by the Laboratorio di Geologia Nucleare, Universita di Pisa and the Laboratoire de Géologie Nucléaire, Université Libre de Bruxelles.

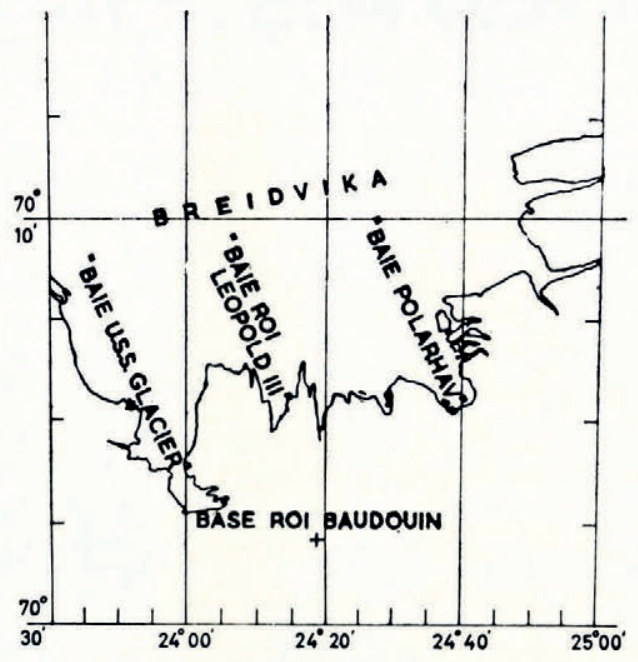

Fig. 2. Outline of Breidvika and the situation of the drilling site at Base Roi Baudouin

\section{Previous Drilling}

Core drillings in ice below a depth of $100 \mathrm{~m}$. are not numerous. One of the first operations of this type was carried out by Expéditions Polaires Françaises on the Greenland Ice Sheet during the summer of $195^{\circ}$ (Heuberger, I 954; Schytt, I958).

$\mathrm{Up}$ to the present only four borings to a depth of over $100 \mathrm{~m}$. in Antarctica are known. The one on the Maudheim Is-shelf (lat. $71^{\circ} 03^{\prime}$ S., long. $10^{\circ} 56^{\prime} \mathrm{W}$.), carried out by the Norwegian-British-Swedish Antarctic Expedition 1949-52, attained a depth of $100 \mathrm{~m}$. (Schytt, 1958). Two other borings have been made by SIPRE in collaboration with American Antarctic expeditions. The one undertaken at Byrd Station on the polar plateau (December 1957-January 1958) reached a depth of $308 \mathrm{~m}$. (Patenaude, 1958; Marshall and Gow, 1958); the other, at Little America V Station on the Ross Ice Shelf, penetrated through the whole shelf and reached the sea at $225 \mathrm{~m}$. (October-December 1958) (Ragle and others, 1960). The Soviet Antarctic Expedition (second Continental Expedition 1956-58) also carried out a deep boring $7 \mathrm{~km}$. south of "Mirnyy", which reached a depth of $37 \mathrm{I} \mathrm{m}$. (Shumskiy, I960).

\section{The Drilling Operation}

\section{Equipment}

The drilling at Base Roi Baudouin was undertaken with light equipment of a type commonly used for mineral prospecting, which enables a maximum depth of $300 \mathrm{~m}$. to be achieved. The evacuation of cuttings was to be ensured by a circulation of compressed cooled air.

The major items of equipment were as follows:

(I) The drilling machine, manufactured in Sweden by the Craelius Company (type XCH/6o), furnished with a $7 \mathrm{~m}$. derrick and powered by a ${ }_{5}$ h.p. engine. The bit was hydraulically operated and advanced automatically. 
(2) Rods, $3 \mathrm{~m}$. long, $42 \mathrm{~mm}$. and $50 \mathrm{~mm}$. in diameter.

(3) Core barrels, single and double Craelius core barrels with external diameters of 65,75 and $85 \mathrm{~mm}$. and $3 \mathrm{~m}$. in length.

(4) Drill bits, manufactured by the Craelius Company, of different types (toothed, in "Wydia", and non-toothed, in "diamond steel"), with external diameters of 66,76 and $86 \mathrm{~mm}$.

(5) Casing tubes, $3 \mathrm{~m}$. in length and of diameters $77-84$ and $89-98 \mathrm{~mm}$.

(6) An Atlas Copco compressor ( $\mathrm{VT}_{4} \mathrm{Dd}$ ), operated by a 45 h.p. diesel motor. It gave a maximum discharge of $4 \mathrm{~m} .3 / \mathrm{min}$. under a pressure of $7 \mathrm{~kg} . / \mathrm{cm} .{ }^{2}$.

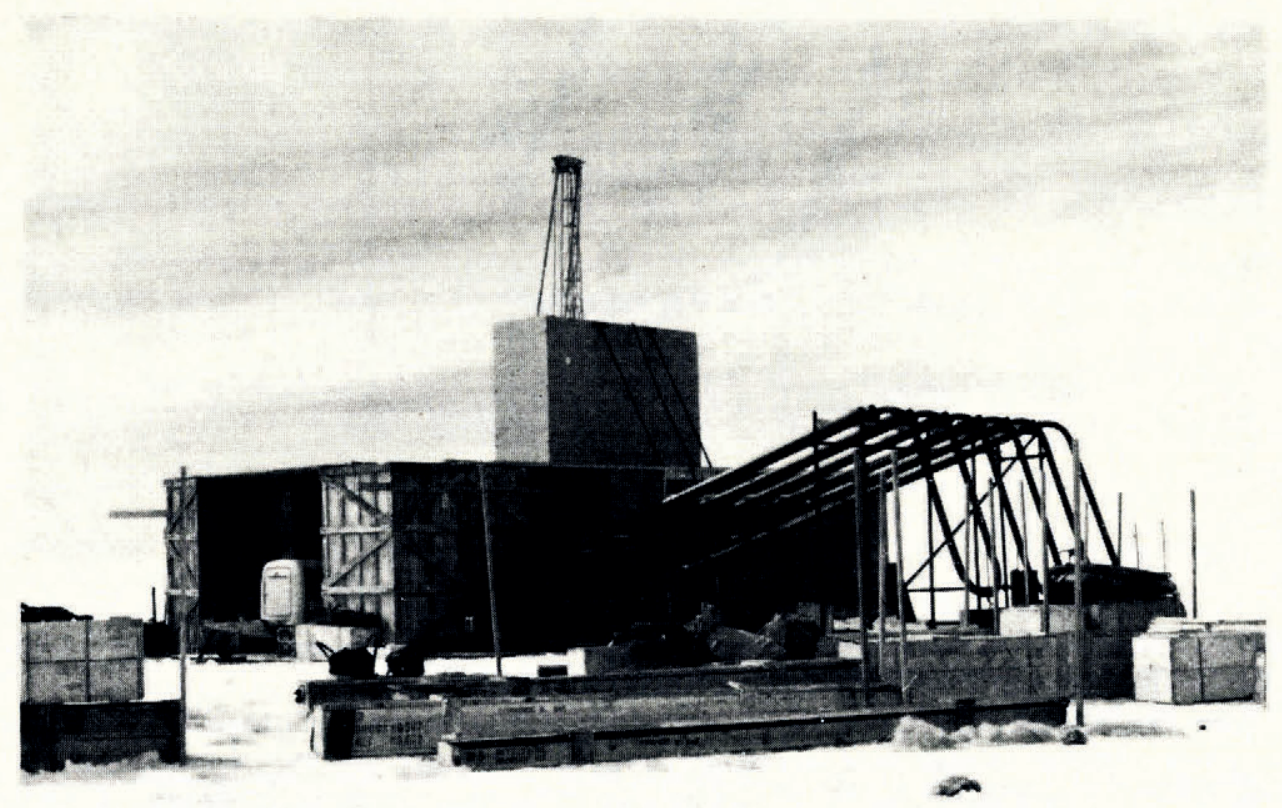

Fig. 3. The shelter with its tower for the derrick, together with the compressor and the cooling system. (Photograph by L. Goossens)

\section{Refrigeration}

The air coming from the compressor was cooled by heat exchange with the atmosphere. It was passed through a system of tubes (total length $58.50 \mathrm{~m} ., 3 \mathrm{in} .(7.6 \mathrm{~cm}$.) in diameter), fitted with two welded fins. Six straight tubes were connected together with U-tubes fitted with cocks for releasing the condensed water.

\section{Shelter}

The drilling machine and its derrick were protected by a prefabricated wooden shelter $(9.76$ by 3.66 by $2.40 \mathrm{~m}$.). In the roof there was a 3.66 by $1.20 \mathrm{~m}$. opening, over which was placed a $2.40 \mathrm{~m}$. high tower which contained the superstructure of the derrick and enabled the rods to be handled in $6 \mathrm{~m}$. sections (Fig. 3). In the event of a blizzard it could be completely closed, the work continuing with a $4 \mathrm{~m}$. high derrick and the rods being handled in $3 \mathrm{~m}$. sections. 
Preliminary trials

Before being shipped to Antarctica the equipment was tested on the Glacier du Géant in the Mont Blanc massif in October 1960. The result was satisfactory.

\section{Drilling operation}

The drilling team consisted of seven members: E. Picciotto (leader of the operation), J. Giot (assistant), T. Norling (engineer), R. Gonfiantini (chemist, C.N.E.N., Universita di Pisa), A. Fontanive, Q. Da Roit and A. Fiocco (drilling technicians of C.N.E.N.). W. De Breuck, the wintering glaciologist, joined the team at Base Roi Baudouin.

The Danish ship Erika Dan, chartered by the C.N.R.P.B., left Zeebrugge on ro December I96o and anchored in "Baie Roi Léopold III" on 9 January I96r.

The time available for the completion of the operation was very short; for various reasons the stay of the ship off the Antarctic coast was limited to a maximum of twenty days.

Drilling started on 12 January on a spot, $2 \mathrm{~km}$. south of the station, outside the zone influenced by it. From the start there were serious difficulties: slow advance, a blocked core barrel after several tens of centimetres drilling, discontinuous and partially melted cores. In five days all the available types of core barrels and drill bits were tried and the drilling reached a depth of $\mathrm{I} 7 \mathrm{~m}$., but with useless cores.

Initially the reason for this setback was thought to be due to the high air temperature which reached $+5^{\circ} \mathrm{C}$. Nevertheless, no further progress was made during the night when the temperature of the compressed air dropped to $-3^{\circ} \mathrm{C}$. The major cause of the drilling difficulties appears to have been the loss of the circulating air in the firn.

In view of the efficiency of the SIPRE coring auger (hand-drill developed by SIPRE and constructed by the General Mechanical Company, Chicago, U.S.A.; length $90 \mathrm{~cm}$., diameter $7.55 \mathrm{~cm}$.) used at the spot and the setbacks of the previous mechanical trials, it was decided to start a new drilling, this time using the SIPRE auger driven by the mechanism of the drilling machine. This procedure proved efficient, the only remaining inconvenience being the short length of the core barrel which necessitated withdrawing it after every 40 to $50 \mathrm{~cm}$. advance. The recovered cores were in excellent condition.

In four days the drill reached a depth of $44 \mathrm{~m}$. with a core yield of almost roo per cent. From a depth of about $40 \mathrm{~m}$. the advance in drilling was between 20 to $30 \mathrm{~cm}$. for every manœuvre. At this stage the drill had reached the zone of high ice density $\left(0.85 \mathrm{~g} . / \mathrm{cm} .{ }^{3}\right)$. According to the experience gained from the American borings, an environment of this density could be expected to be sufficiently compact to allow air circulation during drilling, provided the upper levels were cased. Moreover, the external air temperature had now dropped to between -6 and $-\mathrm{I} 5^{\circ} \mathrm{C}$.

The initial technique was tried again with a $3 \mathrm{~m}$. core barrel but with one important modification: the toothed "Wydia" drill bit was altered by welding vertical ridges onto its outer side. This increased space between the body of the core barrel and the outer wall of the drilled hole varied from I to $5 \mathrm{~mm}$., thus facilitating the passage of the air which was to carry the cuttings upward and out from the hole.

Casing tubes were inserted to a depth of $43 \mathrm{~m}$. so that the air circulation could be used again. In three days the drilling reached a depth of $79.33 \mathrm{~m}$. with a core recovery close to Ioo per cent.

From this depth downwards the coring was incomplete and the recovered core fragments rarely exceeded $\mathrm{r} 0 \mathrm{~cm}$. in length. This fragmentation appears to have been caused by a weakness in the cores along pre-existing horizontal fractures in the ice.

On 27 January the drilling had reached a depth of $115.72 \mathrm{~m}$., with an average core yield of 55 per cent between $79 \cdot 33$ and II $5.72 \mathrm{~m}$. Due to a technical accident the core barrel became blocked at this depth.

Because of the satisfactory results of the drilling operation and the alarming state of the 
bay ice, it was decided to abandon the rods and the core barrel in order to embark on the ship as rapidly as possible. The re-embarkation of men, samples and equipment was completed at midnight on 29 January $196 \mathrm{I}$.

\section{Technical discussion}

From a technical point of view the drilling may be subdivided into three sections (Table I).

(I) Dry drilling with the SIPRE auger.

(2) Drilling with circulating air and a $3 \mathrm{~m}$. double core barrel, giving almost complete core recovery.

(3) Drilling with the same equipment as above but with an incomplete core yield.

The appropriate results for these sections are shown in Table I.

Table I. Characteristics of the Three Drill Sections

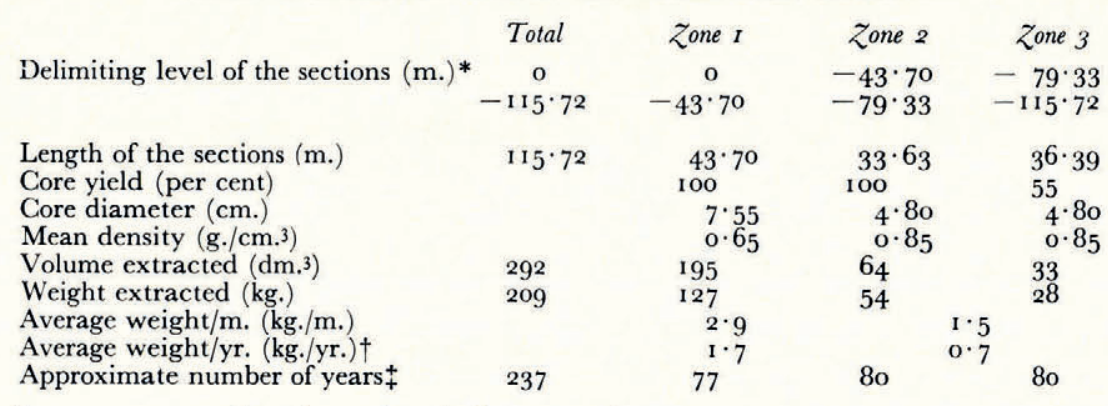

* The figure o corresponds to the surface in January $196 \mathrm{r}$.

$\dagger$ Estimated according to the stratigraphy.

‡ Assuming an average annual accumulation of $38 \mathrm{~cm}$. water equivalent over the whole drilling.

For both types of core barrel used the optimum conditions for obtaining good cores would appear to be a rotation speed of about 100 r.p.m. and the drill pressure near zero.

The use of the SIPRE auger, as already suggested by Schytt (1958), has the advantage of not requiring air circulation and therefore allows operation with very light equipment. The numerous manœuvres, the principal inconvenience of this method, could be reduced by using a longer core barrel. The core jammed in the barrel after an advance of only 15 to $20 \mathrm{~cm}$., when the density approached that of ice. This was probably caused by the hard ice cuttings wedging between the core and the barrel.

For the drilling with the use of compressed air, a high ice density is essential. This method, which gave excellent yields down to $300 \mathrm{~m}$. when used for the American drilling, proved to be inefficient in the present case below a depth of $70 \mathrm{~m}$. This unfavourable result could be ascribed to the difference in the core diameters, which were $10 \mathrm{~cm}$. (for the SIPRE cores) and $4.8 \mathrm{~cm}$. respectively. The much heavier SIPRE equipment ensured greater rigidity of the rods and a well-centered rotation of the core barrel.

In the present drilling the small diameter of the rods caused an eccentric rotation of the core, which was undoubtedly accompanied by heavy vibrations. These factors, coupled with the small diameter of the ice cylinder and the initial presence of numerous fractures and tension cracks perpendicular to the drill axis (also noted in the American drillings), would explain the severe fragmentation of the core as it was cut and also the subsequent loss.

With the equipment and techniques used for the drilling at Base Roi Baudouin a depth of I $00 \mathrm{~m}$., with complete coring and undisturbed cores of 4 to $7 \mathrm{~cm}$. diameter, can be achieved in a few days under normal conditions of snow cover on an Antarctic ice shelf. 


\section{Preliminary Observations}

During the drilling a preliminary stratigraphic description of the upper zone from o to $43 \mathrm{~m}$., as well as measurements of density, were undertaken. Due to the limited time available, the planned temperature measurements could not be made in the drill hole.

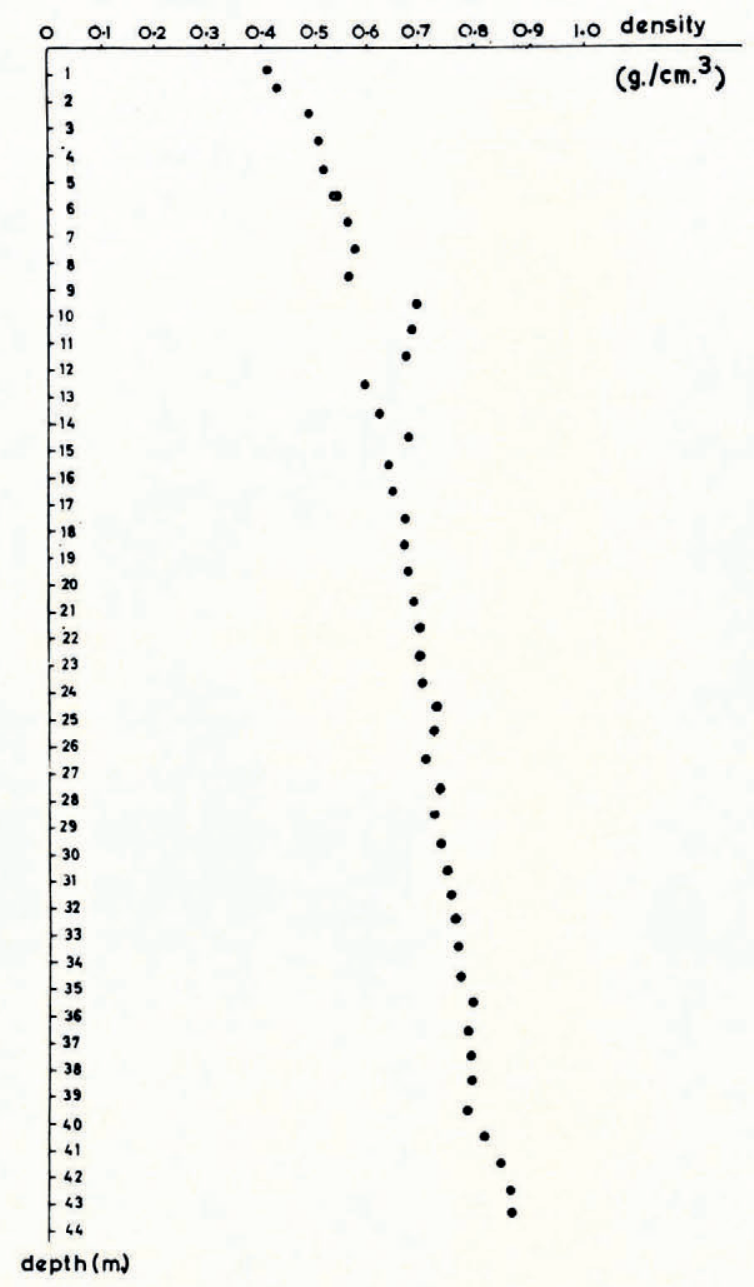

Fig. 4. Variation of the density as a function of depth

\section{Density}

The curve in Figure 4 shows the variations of the density as a function of the depth, integrated over I m. sections.

The density increases as a function of the depth in a way similar to that found by the Norwegian-British-Swedish Antarctic Expedition at Maudheim, and by the Americans on the Ross Ice Shelf.

The marked scatter of the points lying between 9 and ${ }_{1} 3 \mathrm{~m}$. is due to the presence of several ice layers. 

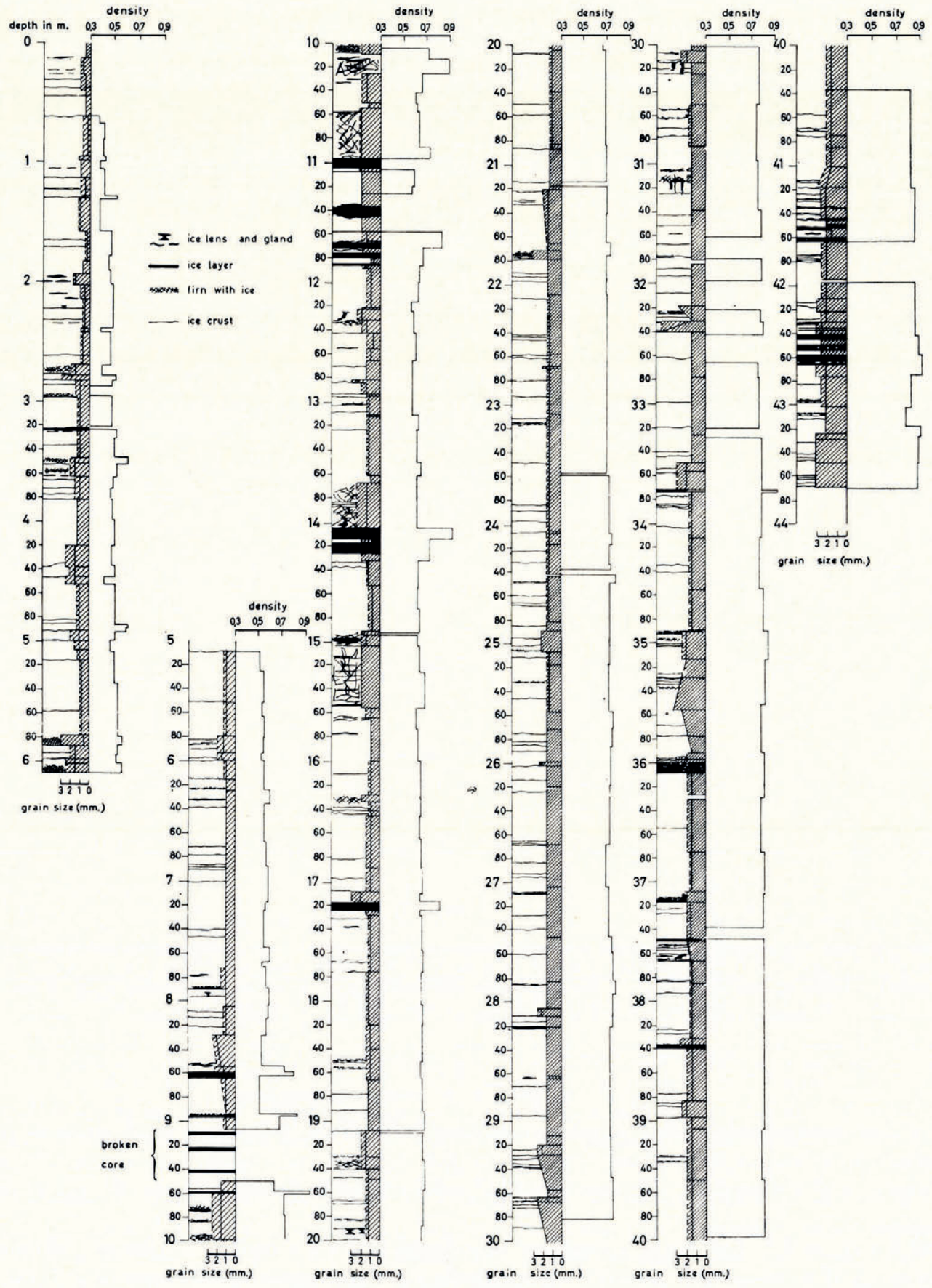

Fig. 5. Stratigraphic profile between o and $43 \mathrm{~m}$. 


\section{Stratigraphy}

A preliminary stratigraphic section is presented in Figure 5 .

The horizontal stratification is marked by:

(a) Variations in the diameter of the grains evaluated with a magnifying lens. These variations are attenuated with increasing depth.

(b) Layers of ice crust of between 0.5 and $2.0 \mathrm{~mm}$. thickness, which are noticeable even in the compact ice at depths greater than $40 \mathrm{~m}$.

(c) Layers and lenses of ice, which may attain thicknesses up to $10 \mathrm{~cm}$.

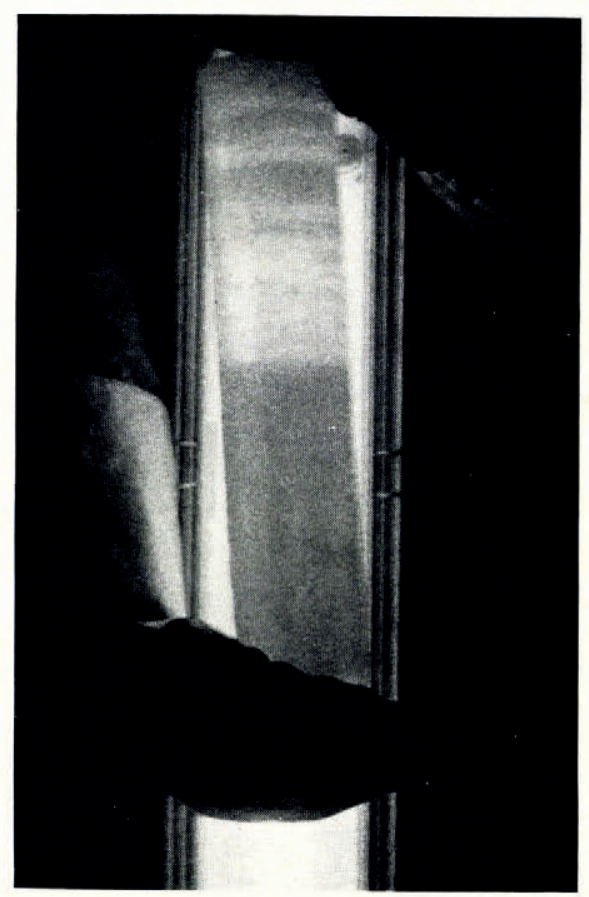

Fig. 6. A sectioned core $7.55 \mathrm{~cm}$. in diameter. The core is placed in front of a fluorescent tube. The seasonal alternation is well marked; the summer layer in the upper part is formed of firn and the many layers of ice indicate a particularly warm summer. The winter layer is formed of homogeneous firn with a fine grain

No coloured or dust-rich layers were noticed. Seasonal alternations were often detected, on the basis of the criteria defined by Schytt (1958). Summer layers are characterized by larger grains, and by the presence of ice, in strata or in lenses (Fig. 6).

These seasonal alternations are clearly defined for the last six years, and enable the following estimates to be made for the annual accumulation, in $\mathrm{cm}$. of water, for the years between I954 and I959:

\begin{tabular}{|c|c|}
\hline $1959 \quad 4^{\mathrm{I}} \cdot 5$ & I $95^{6}$ \\
\hline $33 \cdot 2$ & I955 \\
\hline $3^{8} \cdot 3$ & I 954 \\
\hline
\end{tabular}

A striking feature of the stratigraphic profile is the existence of two zones characterized by an intense formation of dense ice:

from 9 to $16 \mathrm{~m}$.

and from $4^{\mathrm{I}}$ to $44 \mathrm{~m}$. (or morc). 
Each zone corresponds with a period of several consecutive years ( 5 to io), with hot summers, and a maximum temperature lying above $0^{\circ} \mathrm{C}$. These two zones could be considered as corresponding to the years $1949-39$ and $1890-80$.

Any discussion of these results would be premature at this early stage of the proposed morphological and geochemical investigations.

\section{Future Investigations}

A detailed stratigraphic and morphological investigation of the cores, stored for the present at $-\mathrm{I} 5^{\circ} \mathrm{C}$., is planned. The programme of geochemical study of the cores provides for the following measurements :

(I) Isotopic composition of oxygen and hydrogen.

(2) Concentration of tritium and radium $\mathrm{D}$.

(3) Chemical composition of the snow and the occluded gases.

(4) Investigation of dust content.

\section{Acknowledgements}

We wish to acknowledge the assistance of all the members of the Expédition Antarctique Belge, commanded by Guy Derom, and especially MM. J. Dubois, M. Foccroulle, Adj. M. Pierre and Cdt. Ph. de Jamblinne of the summer party, which took an active part in the drilling operation. Thanks are also extended to the Centre National de Recherches Polaires de Belgique.

$M S$. received 3 August $196 \mathrm{I}$

\section{REFERENCES}

Epstein, S., and Sharp, R. P. I959[a]. Oxygen isotope variations in the Malaspina and Saskatchewan Glaciers. Journal of Geology, Vol. 67, No. 1, p. 88-102.

Epstein, S., and Sharp, R. P. I959[b]. Oxygen isotope studies. Transactions. American Geophysical Union, Vol. 40, No. I, p. 81-84; I.G.Y. Bulletin (Washington, D.C.), No. 2 I, p. 9-1 2.

Gonfiantini, R., and Picciotto, E. 1959. Oxygen isotope variations in Antarctic snow samples. Nature, Vol. I84, No. 4698 , p. $1557-58$.

Heuberger, J.-C. I 954. Glaciologie. Groenland. Vol. 1 : forages sur l'inlandsis. Paris, Hermann. (Actualités scientifiques et industrielles, 1214 . Expéditions Polaires Françaises [travaux], 5.)

Marshall, E. W., and Gow, A. J. 1958. Core drilling in ice, Byrd Station, Antarctica. Part II. Core examination and drill hole temperatures. I.G.Y. Glaciological Report Series (New York, I.G.Y. World Data Center A, Glaciology, American Geographical Society), No. I, p. V-6-Io.

Patenaude, R. W. 1958. Core drilling in ice, Byrd Station, Antarctica. Part I. Drilling techniques. I.G.Y. Glaciological Report Series (New York, I.G.Y. World Data Center A, Glaciology, American Geographical Society), No. I, p. $\mathrm{V}-\mathrm{I}-5$.

Picciotto, E., and others. I960. Isotopic composition and temperatures of formation of Antarctic snows, by E. Picciotto, X. de Maere [d'Aertrycke] and I. Friedman. Nature, Vol. 187, No. 4740, p. 857-59.

Ragle, R. H., and others. I960. Deep core drilling in the Ross Ice Shelf, Little America V, Antarctica, by R. H. Ragle, B. L. Hansen, A. [J.] Gow and R. W. Patenaude. U.S. Snow, Ice and Permafrost Research Establishment. Technical Report 70.

Schytt, V. 1958. The inner structure of the ice shelf at Maudheim as shown by core drilling. Norwegian-BritishSwedish Antarctic Expedition, 1949-52. Scientific Results (Oslo, Norsk Polarinstitutt), Vol. 4, C, p. I $13-52$.

Shumskiy, P. A. 1960. Osnovnyye rezul'taty issledovaniya antarkticheskogo lednikovogo pokrova [Main results of study of the Antarctic ice sheet]. (In Treshnikov, A. F., ed. Vtoraya kontinental'naya ekspeditsiya 1956 -1958 gg. Nauchnyye rezul'taty [Second continental expedition, ${ }_{1956-58}$. Scientific results]. Leningrad, Izdatel'stvo "Morskoy Transport" ["Morskoy Transport" Publishing House], p. I 26-70. [Numbered "9".]) 